\title{
PERIFERIA DE ALFONSO REYES
}

UNO

El joven poeta llega al estudio de la literatura por el camino de la pasión: el gusto incontinente, que precede al alfabeto, por el acontecimiento - y por la palabra que trasciende el acontecimiento. El joven poeta llega al estudio de la literatura por el insomnio verbal, por la imposición de la lectura, que aplaza todo lo demás, aun el amor. El joven poeta llega al estudio de la literatura por la memoria inevitable del poema, que le resuelve la vida, el ánimo, la incredulidad.

Y cuando el joven poeta llega al estudio de la literatura, impulsado por doce novelas azarosas y veinte poemas de amor, el estudio de la literatura le parece arduo o estéril. El joven poeta no quiere saber de métodos, de estructuras narrativas, de teorías literarias. Siente que le revelan el misterio: que le anticipan el desenlace o que le rompen el poema - que se lo descomponen. Hay algo de profanación en el estudio de la literatura: como si lo más personal, lo intransferible, se expusiera sin pudor al concurso de los ajenos, de los otros. Hay algo de despojo. Y es que el joven poeta piensa, vanidoso y tímido a un tiempo, como Stephen Dedalus, como Franz Kappuz, como Jeromil, que él es el único receptáculo de la palabra: que el tiraje de los libros amados es de un solo ejemplar, como el de sus poemas.

Y como sólo el joven poeta "sabe qué grande es el deseo de no ser poeta, el deseo de abandonar esa casa de espejos en la que reina un silencio ensordecedor", un día se asoma a un género que no es el de la iniciación sino el de la madurez: el ensayo, "el centauro de los géneros", como lo llamó Alfonso Reyes, "donde hay de todo y cabe todo" y que responde al infinito universo del Etcétera. Y ese día, el joven poeta, que ha leído cuanto ha leído por 
mera pasión de lector ingenuo, diría Bachelard, emprende el camino del lector profesional: sin dejar de ser amante de la literatura, empieza a ser marido de la literatura: cotidiano, fiel, disciplinado y constante. Y encuentra una nueva forma de la pasión, la que Octavio Paz ha llamado pasión crítica: la pasión por la inteligencia, por el conocimiento y aun por la erudición, que no niegan sino fortalecen la imaginación primordial. A propósito de sus ensayos, el progenitor del ensayo dijo: "Éstas son mis fantasías, por las cuales intento dar un conocimiento no de las cosas, sino de mí mismo"'.

De la lectura de La rama dorada, Historia trágica de la literatura, Amor y Occidente, El nacimiento de la tragedia, el joven poeta cobra la certidumbre de que las obras a las que hacen alusión semejantes monumentos literarios configuran un mundo referencial tan verídico como el de su geografía o el de su corazón. La literatura de la literatura: de su historia, de sus vaivenes, de sus implicaciones, de sus orígenes. $Y$ también de su esencia y de sus accidentes: su teoría.

La lectura de $E l$ deslinde de Alfonso Reyes es un tropiezo primerizo con la lucidez. Su densidad no se debe a la complicación de su materia sino a la claridad de su exposición, que deslumbra y enceguece. Por su exactitud y por su transparencia, El deslinde es como el álgebra en el símil de Borges: un palacio de precisos cristales.

A partir de su lectura, el joven poeta dejó de leer despatarrado en la cama; empezó a leer sentado al escritorio, con el lápiz presto, alternando el cuaderno de notas con el libro y volviendo cursivas las redondas: los subrayados son suyos.

Ahora que el joven poeta dejó de serlo, cuando lee en un autobús o en una hamaca o en el baño - lugar donde Alfonso Reyes, por cierto, alojaba la sección de novelas policiacas de su inconmensurable biblioteca-, sabe que empieza a ir -o a venir- de regreso de las cosas.

Dos

Reyes y Borges se consideraron, recíprocamente, los mejores prosistas de nuestro continente y aun de nuestra lengua. A saber dónde comenzó el círculo virtuoso.

De serlo, lo son por motivos diferentes.

Borges es un poeta aun para escribir prosa. No porque escri- 
ba poesía en prosa o prosa poética - que, por su inevitable hibridez, son modalidades literarias imprecisas-, sino porque hay en su escritura una voluntad de síntesis, de implacable selección verbal. En cambio Reyes es, ante todo, un prosista, si bien dejó constancia poética no sólo en la lírica, sino en la épica de su versión fragmentaria de La Ilíada y en la dramática de Ifigenia cruel: su discurso es generoso y prolijo y tiene la abundancia propia de la voluntad analítica. Asombra, por ello, su rigor. Si Borges pinta miniaturas, Reyes practica el muralismo pero a fuer de pinceladas breves y precisas.

Borges - como alguna vez confesó- rumia en el silencio de su ceguera cada frase y así, cuando la dicta, ya es, que él sepa, perfecta. Reyes, corrector infatigable de su extensa obra hasta la fijación determinante de la imprenta, escribe, empero, en voz alta: parecería que no tuviera, como Cervantes, la oportunidad del borrador; que dada una primera frase, acaso fallida o errática, resolviera su desenvolvimiento en el ejercicio mismo de la escritura.

Borges se asoma a su texto en los paréntesis que abre el otro Borges para hacer sus reflexiones metaliterarias, tantas veces irónicas, siempre críticas. Más que los paréntesis, Reyes disfruta las notas al pie de página y los índices onomásticos donde los otros Reyes - los infinitos pensadores absorbidos por el humillante patrimonio verbal de don Alfonso- quedan debidamente registrados para pasar a la residencia de la obra, que alguien maliciosamente consideró casa de citas. Pero acaso lo que más defina al estilo de Reyes sea la puntuación, que revela la estructura prístina de su pensamiento. Podría pensarse, llevando las cosas al extremo de la hipérbole, que la puntuación precede al texto mismo. $Y$ es que se puede cambiar una palabra, pero no un punto y coma. Cada punto y coma de Alfonso Reyes es como un par de banderillas clavado con maestría en el indómito toro de la prosa.

Si algo une profundamente a Borges y a Reyes, amén de su infatigable búsqueda de la perfección formal y su sentido del humor, es su entendimiento de la vida como un texto literario. Aun los placeres más mundanos de Reyes - de la gastronomía al erotismo- lo son por la palabra. Y las obsesiones de Borges - tigres, espejos, laberintos- no son más que otras tantas metáforas de su obsesión esencial: la escritura. Para Borges, el universo y su autor - divino laberinto de los efectos y de las causas- son un lenguaje cifrado que el hombre se empeña, vanamente, en descrifrar. Si la vida es una sucesión de textos, Borges y Reyes, al escribir, escriben que escriben: grafógrafos en suma, diría Salva- 
dor Elizondo. Borges, que se figuraba el paraíso bajo la especie de una biblioteca, imaginó la Biblioteca infinita de Babel. Reyes, simplemente, la habitó.

TRES

Leí $E l$ deslinde en la Biblioteca de El Colegio de México. Leí $E l$ deslinde sin camisa, porque a Alfonso Reyes, como dice José Emilio Pacheco, hay que leerlo por placer y no por obligación, y porque la de El Colegio de México, como todas las bibliotecas, requiere la desnudez del lomo para la catalogación del libro.

Cuando pude adquirir las obras completas de Alfonso Reyes, merced al empeño de mi amor adolescente, no quise proteger la camisa protectora y, conforme los iba leyendo, fui descamisando los libros en señal de pertenencia, como constancia poética. Y cuando hube descamisado los diecinueve volúmenes de entonces, creí cumplida la consigna de mi maestro Ernesto Mejía Sánchez.

- Maestro, ¿por cuál obra de Reyes debo empezar? -le había preguntado.

-Empieza por sus obras completas - me había respondido con la memoria posada en el prólogo a $E l$ deslinde, donde Reyes dice que a los jóvenes "no queda otro remedio que confesarles: lo primero es conocerlo todo, y por ahí se comienza".

Contar, en la historia de la literatura mexicana, con la obra de Alfonso Reyes es una garantía de supervivencia. No por el dudoso prestigio de lo cuantitativo, que Rulfo se encargó de desmentir, sino porque gracias a ella, como gracias a la obra de Carpentier, de Borges o de Lezama Lima, México e Hispanoamérica tienen relación con la cultura universal. Y en la cultura universal está lo nuestro. Es más: porque se conoce todo, como quería Reyes, comenzamos a saber de nosotros; porque sabemos de Áulide y de Táuride, sabemos que Ifigenia cruel podría haberse llamado Juana González.

El tema es obligado. Por lo mismo no puedo decir nada novedoso. Alfonso Reyes, ciertamente, es el mexicano universal: la visión de Anáhuac y la religión griega (porque en Grecia siempre hubo más dioses que hombres); el pasado inmediato de la literatura mexicana y la crítica en la edad ateniense, las letras de la Nueva España y los historiadores alejandrinos...

Ignoro cuál es la importancia de la obra alfonsina en el estudio universal de la cultura universal. Sé, en cambio, que, en un 
país que llegó tarde al banquete de la cultura, como dice el propio Reyes, y donde en aras de un nacionalismo patriotero con harta frecuencia se cerraron los oídos a las voces del mundo, la importancia de la obra alfonsina puede resumirse en una paronomasia que, para terminar, dejo caer con mi mayor respeto: "En el país de los ciegos el tuerto es Reyes"'.

Gonzalo Celorio

Universidad Nacional Autónoma de México 